\title{
The First Halide-Free Bimetallic Aluminum Borohydride: Synthesis, Structure, Stability, and Decomposition Pathway
}

Iurii Dovgaliuk, ${ }^{\dagger}$ Voraksmy Ban, ${ }^{\dagger}$ Yolanda Sadikin, ${ }^{\ddagger}$ Radovan Černý, ${ }^{\ddagger}$ Lionel Aranda, ${ }^{\S}$ Nicola Casati,, Michel Devillers, ${ }^{\dagger}$ and Yaroslav Filinchuk ${ }^{*}{ }^{\dagger}$

\author{
${ }^{\dagger}$ Institute of Condensed Matter and Nanosciences, Université catholique de Louvain, Place L. Pasteur 1, 1348 Louvain-la-Neuve, \\ Belgium \\ ${ }^{\ddagger}$ Laboratory of Crystallography, DPMC-MaNEP, University of Geneva, quai Ernest-Ansermet 24, 1211 Geneva, Switzerland \\ ${ }^{\S}$ Faculté des Sciences, Institut Jean Lamour (UMR 7198), BP 70239, 54506 Vandoeuvre-lès-Nancy, France \\ ${ }$ Swiss Light Source, Paul Scherrer Institute, WLGA/229, 5232 Villigen, Switzerland
}

Supporting Information

ABSTRACT: Interaction of solid $\mathrm{KBH}_{4}$ with liquid $\mathrm{Al}\left(\mathrm{BH}_{4}\right)_{3}$ at room temperature yields a solid bimetallic borohydride $\mathrm{KAl}\left(\mathrm{BH}_{4}\right)_{4}$. According to the synchrotron X-ray powder diffraction, its crystal structure (space group Fddd, $a=9.7405(3), b=12.4500(4)$, and $c=14.6975(4) \AA$ ) contains a substantially distorted tetrahedral $\left[\mathrm{Al}\left(\mathrm{BH}_{4}\right)_{4}\right]^{-}$anion, where the borohydride groups are coordinated to aluminum atoms via edges. The $\eta^{2}$-coordination of $\mathrm{BH}_{4}{ }^{-}$is confirmed by the infrared and Raman spectroscopies. The title compound is the first aluminum-based borohydride complex not stabilized by halide anions or by bulky organic cations. It is not isostructural to bimetallic chlorides, where more regular tetrahedral $\mathrm{AlCl}_{4}^{-}$anions are present. Instead, it is isomorphic to the LT phase of $\mathrm{TbAsO}_{4}$ and can be also viewed as consisting of two interpenetrated dia-type nets where $\mathrm{BH}_{4}$ ligand is bridging $\mathrm{Al}$ and $\mathrm{K}$ cations. Variable temperature X-ray powder diffraction, TGA, DSC, and TGA-MS data reveal a single step of decomposition at $160{ }^{\circ} \mathrm{C}$, with an evolution of hydrogen and some amount of diborane. Aluminum borohydride is not released in significant amounts; however, some crystalline $\mathrm{KBH}_{4}$
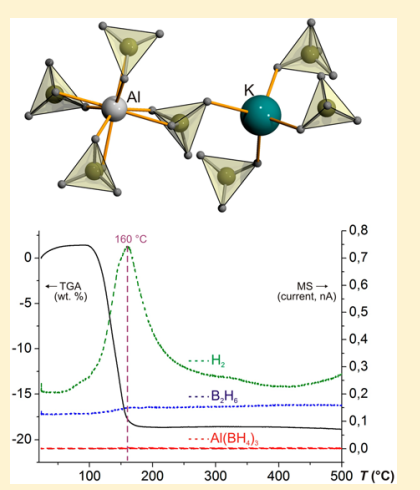
forms upon decomposition. The higher decomposition temperature than in chloride-substituted $\mathrm{Li}-\mathrm{Al}\left(70{ }^{\circ} \mathrm{C}\right)$ and $\mathrm{Na}-\mathrm{Al}(90$ ${ }^{\circ} \mathrm{C}$ ) borohydrides suggests that the larger alkali metal cations (weaker Pearson acids) stabilize the weak Pearson base, $\left[\mathrm{Al}\left(\mathrm{BH}_{4}\right)_{4}\right]^{-}$.

\section{INTRODUCTION}

During the recent years, metal borohydride complexes and their derivatives are among the most exciting materials for potential hydrogen storage due to their high hydrogen content. ${ }^{1}$ Regarding the hydrogen gravimetric and volumetric system targets, recently revised by the U.S. Department of Energy to $5.5 \mathrm{wt} \%$ and $40 \mathrm{~g} / \mathrm{L},{ }^{2}$ most of the alkali and alkali-earth metal borohydrides match them. However, metal borohydrides are quite stable for hydrogen release by thermolysis as they decompose at high temperatures (about $470{ }^{\circ} \mathrm{C}$ for $\mathrm{LiBH}_{4}$ and 290-500 ${ }^{\circ} \mathrm{C}$ for $\left.\left.\mathrm{Mg}\left(\mathrm{BH}_{4}\right)_{2}\right)\right)^{3,4}$ The temperature of desorption can be dramatically reduced for bimetallic borohydride complexes, where the decomposition temperature decreases with increasing Pauling electronegativity for complex anions. The increasing covalence in $\mathrm{M}-\mathrm{H}$ bonding weakens the $\mathrm{B}-\mathrm{H}$ bonding and improves thermal decomposition properties of bimetallic complexes. Among the so far published bimetallic complex borohydrides, there are several that match the temperature range of $60-120{ }^{\circ} \mathrm{C}$ applicable for fuel cells: ${ }^{7}$ " $\mathrm{Li}_{4} \mathrm{Al}_{3}\left(\mathrm{BH}_{4}\right)_{13}$ " containing some chloride on a borohydride site, ${ }^{8} \mathrm{Na}\left[\mathrm{Al}\left(\mathrm{BH}_{4}\right)_{4-x} \mathrm{Cl}_{x}\right],{ }^{9} \mathrm{NaZn}_{2}\left(\mathrm{BH}_{4}\right)_{5}, \mathrm{NaZn}\left(\mathrm{BH}_{4}\right)_{3},{ }^{10}$ $\mathrm{KCd}\left(\mathrm{BH}_{4}\right)_{3}, \quad \mathrm{~K}_{2} \mathrm{Cd}\left(\mathrm{BH}_{4}\right)_{4} \cdot{ }^{11}$ All the mentioned bimetallic borohydrides evolve diborane $\left(\mathrm{B}_{2} \mathrm{H}_{6}\right)$ as hydrogen desorption byproduct which prevents full reversibility and is undesirable for fuel cell applications. This disadvantage is absent for borohydrides which decompose at higher temperatures, ${ }^{12}$ in particular for the bimetallic series $(\mathrm{Li}, \mathrm{Na}, \mathrm{K})[(\mathrm{Sc}, \mathrm{Y})$ $\left.\left(\mathrm{BH}_{4}\right)_{4}\right] \cdot{ }^{13-16}$ Because of the widely used mechanochemical synthesis of novel borohydrides starting from metal borohydrides and halides, most bimetallic systems contain metal halides as secondary phases as well as halide substitution on the borohydride sites. ${ }^{17,18}$ Besides stabilizing new phases that may not exist in $\mathrm{Cl}$-free systems, ${ }^{19}$ this considerably decreases gravimetric capacities of the novel hydrides. From this point of view, it is important to carry out synthesis of new borohydrides by addition with other complex forming borohydrides, like $\mathrm{Al}\left(\mathrm{BH}_{4}\right)_{3}{ }^{20}$

Herein we report on the synthesis, crystal structure, and Raman vibrational spectra together with thermal analysis of $\mathrm{K}\left[\mathrm{Al}\left(\mathrm{BH}_{4}\right)_{4}\right]$ which was first obtained by Semenenko et al. ${ }^{21}$ The synthesis was performed with liquid $\mathrm{Al}\left(\mathrm{BH}_{4}\right)_{3}$ and $\mathrm{KBH}_{4}$ with the aim to prevent formation of possible halide-containing

Received: September 15, 2013

Revised: December 16, 2013

Published: December 16, 2013 
phases, common in case of metathesis reactions between borohydrides and halides. The crystal structure was determined by synchrotron powder diffraction, and further structural characterization was performed with Raman and IR spectroscopy. The thermal stability of the title compound up to $160^{\circ} \mathrm{C}$ is considerably higher than 70 and $90{ }^{\circ} \mathrm{C}$ for the related $\mathrm{Li}_{4} \mathrm{Al}_{3}\left(\mathrm{BH}_{4}\right)_{13}$ and $\mathrm{Na}\left[\mathrm{Al}\left(\mathrm{BH}_{4}\right)_{4-x} \mathrm{Cl}_{x}\right]$. ${ }^{8,9}$ Unlike the Li-based phase, the title compound does not desorb $\mathrm{Al}\left(\mathrm{BH}_{4}\right)_{3}$; however, it eliminates diborane as a decomposition byproduct with 20.8 wt $\%$ mass loss at 12.7 wt $\%$ theoretical hydrogen content.

\section{EXPERIMENTAL DETAILS}

Synthesis. Caution! $\mathrm{Al}\left(\mathrm{BH}_{4}\right)_{3}$ is highly pyrophoric and explosive in contact with moisture and air. In order to prevent explosive reaction of $\mathrm{Al}\left(\mathrm{BH}_{4}\right)_{3}$ with air, all manipulations were carried out in nitrogen-filled Plexiglas glovebox. The starting materials are $\mathrm{AlCl}_{3}$ (95\% Sigma-Aldrich), $\mathrm{KBH}_{4}$ (99\% SigmaAldrich), and $\mathrm{LiBH}_{4}$ (95\% Sigma-Aldrich and 96\% Boss Chemical Industry Co.). The first stage of the synthesis is the preparation of $\mathrm{Al}\left(\mathrm{BH}_{4}\right)_{3}$ from $\mathrm{AlCl}_{3}$ and $\mathrm{LiBH}_{4}$ according to the reaction

$$
\mathrm{AlCl}_{3}+3 \mathrm{LiBH}_{4} \rightarrow \mathrm{Al}\left(\mathrm{BH}_{4}\right)_{3}+3 \mathrm{LiCl}
$$

We have developed a modified procedure of those described in refs 20 and 22. The grinded mixture with $5 \%$ excess of $\mathrm{LiBH}_{4}$ (Boss Chemical Industry Co.) relative to stoichiometry was steadily heated in the glass flask, connected to a tandem of two liquid nitrogen traps. $\mathrm{Al}\left(\mathrm{BH}_{4}\right)_{3}$ starts to evolve as the mixture melts at about $100{ }^{\circ} \mathrm{C}$. At this moment the system was pumped down to $10^{-2} \mathrm{mbar}$, and the product with some $\mathrm{AlCl}_{3}$ impurity is condensed in the traps. The pumping was ended when the mixture stopped boiling. The content of the first trap was unfrozen and purified by distillation at ambient pressure, all in the nitrogen-filled glovebox. The distillation was carried out with Teflon-coated greaseless ground glass joints using a water cooled Liebig condenser. Only the fraction boiling at $44.5^{\circ} \mathrm{C}$ or slightly below was collected in order to separate $\mathrm{Al}\left(\mathrm{BH}_{4}\right)_{3}$ from chloride-containing derivatives.

In the second stage of synthesis, $1-2 \mathrm{~mL}$ of the fresh $\mathrm{Al}\left(\mathrm{BH}_{4}\right)_{3}$ was transferred via a syringe to a bottle with $200 \mathrm{mg}$ of grinded $\mathrm{KBH}_{4}$ powder with continuous stirring. Reaction 2 took place over 4-6 days: ${ }^{21}$

$$
\mathrm{Al}\left(\mathrm{BH}_{4}\right)_{3}+\mathrm{KBH}_{4} \rightarrow \mathrm{K}\left[\mathrm{Al}\left(\mathrm{BH}_{4}\right)_{4}\right]
$$

The excess of volatile $\mathrm{Al}\left(\mathrm{BH}_{4}\right)_{3}$ was removed by pumping with an oil pump for a few minutes. The final products of the reaction were identified by X-ray powder diffraction (XRD). After the first soaking of $\mathrm{KBH}_{4}$ in $\mathrm{Al}\left(\mathrm{BH}_{4}\right)_{3}$, the resulting $\mathrm{KAl}\left(\mathrm{BH}_{4}\right)_{4}: \mathrm{KBH}_{4}$ weight ratio is about $1: 1$. It increases successively after the following soakings, i.e. grinding and stirring with $\mathrm{Al}\left(\mathrm{BH}_{4}\right)_{3}$ liquid, as observed by Semenenko et al. $^{21}$ (Figure S1). Because of the dangerous flammability of $\mathrm{Al}\left(\mathrm{BH}_{4}\right)_{3}$, we did not perform the synthesis with liquid-solid ball-milling. It is worth noting that the yield of $\mathrm{K}\left[\mathrm{Al}\left(\mathrm{BH}_{4}\right)_{4}\right]$ considerably depends on the purity of $\mathrm{Al}\left(\mathrm{BH}_{4}\right)_{3}$ : the monoclinic $\mathrm{KAlCl}_{4}^{23}$ forms as a side product if $\mathrm{Al}\left(\mathrm{BH}_{4}\right)_{3}$ is not purified by distillation (see Figure S2).

A similar procedure was made by soaking the $2 \mathrm{LiBH}_{4}: \mathrm{KBH}_{4}$ mixture in excess $\mathrm{Al}\left(\mathrm{BH}_{4}\right)_{3}$ and removing its excess in vacuum, yielding $\mathrm{LiK}\left(\mathrm{BH}_{4}\right)_{2}$ and $\mathrm{K}\left[\mathrm{Al}\left(\mathrm{BH}_{4}\right)_{4}\right]$ (see Figure $\mathrm{S} 3$ ). The mixtures were grinded with agate mortar in an argon-filled inert glovebox and introduced into $0.7 \mathrm{~mm}$ diameter glass capillaries which were sealed with inert vacuum grease for the following powder diffraction and Raman spectroscopic measurements.

Ball-milling of the $9 \mathrm{LiBH}_{4}+3 \mathrm{KBH}_{4}+2 \mathrm{AlCl}_{3}$ mixture also leads to a formation of $\mathrm{K}\left[\mathrm{Al}\left(\mathrm{BH}_{4}\right)_{4}\right]$, in a mixture with $\mathrm{LiCl}$ and $\mathrm{LiK}\left(\mathrm{BH}_{4}\right)_{2}$ (see Figure $\left.\mathrm{S} 4\right)$. We will not focus our attention on this sample, as it is not Cl-free.

X-ray Powder Diffraction Analysis. Samples were filled into $0.5 \mathrm{~mm}$ thin-walled glass capillaries and sealed under an inert atmosphere. Laboratory diffraction data were obtained with a MAR345 diffractometer, rotating anode $\mathrm{MoK} \alpha$ radiation, and XENOCS focusing mirror.

The $2 \mathrm{LiBH}_{4}: \mathrm{KBH}_{4}: \mathrm{Al}\left(\mathrm{BH}_{4}\right)_{3}$ sample was characterized by temperature-variable in situ powder X-ray diffraction at SNBL, ESRF (Grenoble, France) with a PILATUS $2 \mathrm{M}$ pixel detector and $\lambda=0.82727 \AA$ wavelength synchrotron $\mathrm{X}$-ray radiation. Temperature was increased linearly in time using Oxford Cryostream $700+$ at $5{ }^{\circ} \mathrm{C} / \mathrm{min}$ rate. A sample with $\sim 90$ wt $\%$ of $\mathrm{KAl}\left(\mathrm{BH}_{4}\right)_{4}$ was measured with $\lambda=0.682525 \AA$ at room temperature. The $2 \mathrm{D}$ images were azimuthally integrated using Fit2D program and data on $\mathrm{LaB}_{6}$ standard. ${ }^{24}$

The $\mathrm{KBH}_{4}: \mathrm{Al}\left(\mathrm{BH}_{4}\right)_{3}$ sample was studied at Materials Science Beamline at PSI (Villigen Switzerland), ${ }^{25}$ using a Mythen II detector and $\lambda=0.818109 \AA$. Temperature was increased from 30 to $210^{\circ} \mathrm{C}$ in steps of $10{ }^{\circ} \mathrm{C}$. The $\mathrm{LiBH}_{4}: \mathrm{KBH}_{4}: \mathrm{AlCl}_{3}$ sample was measured at room temperature with $\lambda=0.82712 \AA$.

The rehydrogenation of the $\mathrm{K}\left[\mathrm{Al}\left(\mathrm{BH}_{4}\right)_{4}\right] / \mathrm{KBH}_{4}$ sample was tested using a sapphire-based cell for in situ synchrotron powder diffraction ${ }^{26}$ at Materials Science Beamline, using Mythen II detector and $\lambda=0.775045 \AA$. The starting powder was held in a single-crystal sapphire $\left(\mathrm{Al}_{2} \mathrm{O}_{3}\right)$ capillary with 1.09 $\mathrm{mm}$ outer diameter. The decomposition of the $\mathrm{K}\left[\mathrm{Al}\left(\mathrm{BH}_{4}\right)_{4}\right]$ under 1 bar of $\mathrm{H}_{2}$ was performed by heating the capillary from room temperature to $210^{\circ} \mathrm{C}$ with $5{ }^{\circ} \mathrm{C} / \mathrm{min}$ heating rate. The decomposed sample was cooled to $50{ }^{\circ} \mathrm{C}$ under 100 bar of $\mathrm{H}_{2}$; the powder diffraction data were collected on the system for 70 min. An additional experiment was done by heating the same sample to $320{ }^{\circ} \mathrm{C}$ and subsequent cooling it from this temperature at $10{ }^{\circ} \mathrm{C} / \mathrm{min}$ rate to the room temperature under 100 bar of $\mathrm{H}_{2}$.

The orthorhombic crystal lattice of $\mathrm{K}\left[\mathrm{Al}\left(\mathrm{BH}_{4}\right)_{4}\right]$ was indexed and the structure was solved in Fddd space group with the program $\mathrm{FOX}^{27}$ and refined with the Rietveld method using Fullprof. $^{28}$ The symmetry was confirmed with the ADDSYM routine in the program PLATON. ${ }^{29}$ The structure was solved and refined with $\mathrm{BH}_{4}^{-}$groups as semirigid ideal tetrahedra with one common refined $\mathrm{B}-\mathrm{H}$ distance of $1.13 \AA$. No other restraints were used. Rietveld refinement suggested a negligibly small chloride substitution of $0.03(1)$ on the borohydride site, confirming the Cl-free composition.

Infrared and Raman Spectra. These spectra were recorded at room temperature respectively with a FTIR8400 S Shimadzu spectrophotometer in the $400-4000 \mathrm{~cm}^{-1}$ range and with a Bruker RFS 100/s FT-Raman spectrometer (I $=200 \mathrm{~mW})$ in $100-4000 \mathrm{~cm}^{-1}$ using a diode-pumped, aircooled Nd:YAG laser for $1064 \mathrm{~nm}$ excitation. For the IR measurements the sample was mixed with $\mathrm{KBr}$ matrix in an inert atmosphere. Pure $\mathrm{KBr}$ was used for background subtraction.

TGA and DSC Analysis. This analysis was made on powder samples after preliminary X-ray powder diffraction analysis. The data were collected independently with a TGA/SDTA 851 Mettler and a DSC 821 Mettler instrument with the heating rate of $5{ }^{\circ} \mathrm{C} / \mathrm{min}$ from 25 to $500{ }^{\circ} \mathrm{C}$. The samples for the TGA 
and DSC analysis were loaded in the argon inert glovebox into crucibles with caps or sealed into aluminum pans, respectively. The experiments were done under $10 \mathrm{~mL} / \mathrm{min}$ nitrogen flow to prevent the oxidizing reactions.

TGA Coupled with Mass Spectrometry (MS). TGA-MS was measured using two independent setups: (1) ThermoStar GSD $301 \mathrm{~T}$ spectrometer coupled with simultaneous TGA/ DTA 851 Mettler and (2) Omnistar GSD 301C-Pfeiffer Vacuum spectrometer coupled with SETARAM Setsys Ev 1750 TGA instrument. The measurements were done under 10 $\mathrm{mL} / \mathrm{min}$ argon flow with the heating rate of $2{ }^{\circ} \mathrm{C} / \mathrm{min}$ in $25-$ 300 and $20-500{ }^{\circ} \mathrm{C}$ temperature ranges, respectively.

\section{RESULTS AND DISCUSSION}

Phase Analysis of in Situ Synchrotron Powder Diffraction Data. The X-ray powder diffraction analysis was performed for ternary $\mathrm{Li}-\mathrm{K}-\mathrm{Al}$ and binary $\mathrm{K}-\mathrm{Al}$ borohydride systems; the details are given in the Supporting Information, Figure $\mathrm{S} 3$. The trimetallic $\mathrm{Li}-\mathrm{K}-\mathrm{Al}-\mathrm{BH}_{4}$ system contains $\mathrm{LiBH}_{4}$ as $\mathrm{LT}$ and $\mathrm{HT}$ polymorphs (within their stability ranges), ${ }^{30} \mathrm{KBH}_{4}{ }^{31} \mathrm{LiK}\left(\mathrm{BH}_{4}\right)_{2},{ }^{32}$ and a new bimetallic phase, $\mathrm{K}\left[\mathrm{Al}\left(\mathrm{BH}_{4}\right)_{4}\right]$. The formation of $\mathrm{K}\left[\mathrm{Al}\left(\mathrm{BH}_{4}\right)_{4}\right]$ is more favorable than that of $\mathrm{Li}_{4} \mathrm{Al}_{3}\left(\mathrm{BH}_{4}\right)_{13}$ or a hypothetical $\mathrm{Li}\left[\mathrm{Al}\left(\mathrm{BH}_{4}\right)_{4}\right]$ because the $\mathrm{Li}$ atom is a weaker donor of electrons compared to $\mathrm{K}$. In other words, $\mathrm{K}$ stabilizes better the $\left[\mathrm{Al}\left(\mathrm{BH}_{4}\right)_{4}\right]^{-}$complex.

The known bimetallic $\mathrm{LiK}\left(\mathrm{BH}_{4}\right)_{2}$ forms readily at room temperature, in contrast to the $120^{\circ} \mathrm{C}$ annealing required for the $\mathrm{LiBH}_{4}: \mathrm{KBH}_{4}$ sample. ${ }^{32}$ Formation of $\mathrm{LiK}\left(\mathrm{BH}_{4}\right)_{2}$ in the mild conditions is thus mediated by $\mathrm{Al}\left(\mathrm{BH}_{4}\right)_{3}$. It can be explained by partial solubility of solid $\mathrm{LiBH}_{4}$ and $\mathrm{KBH}_{4}$ borohydrides in liquid $\mathrm{Al}\left(\mathrm{BH}_{4}\right)_{3}$, facilitating the addition reaction. Notably, $\mathrm{LiK}\left(\mathrm{BH}_{4}\right)_{2}$ in our sample decomposes into the $\mathrm{LiBH}_{4}+\mathrm{KBH}_{4}$ mixture at much lower temperatures than reported previously, namely at $95{ }^{\circ} \mathrm{C}$ against $240{ }^{\circ} \mathrm{C}$ attributed to melting and $380{ }^{\circ} \mathrm{C}$ for the decomposition. ${ }^{32}$ The disappearance of diffraction peaks from $\mathrm{LiK}\left(\mathrm{BH}_{4}\right)_{2}$ correlates nicely with increasing intensities from $\mathrm{LiBH}_{4}$ and $\mathrm{KBH}_{4}$. This observation confirms the theoretical conjecture that $\mathrm{LiK}\left(\mathrm{BH}_{4}\right)_{2}$ is unstable with respect to decomposition into $\mathrm{LiBH}_{4}$ and $\mathrm{KBH}_{4}{ }^{33}$ as the decomposition temperatures apparently do not reflect the equilibrium state but the kinetic barriers intrinsic to a particular multicomponent system, in particular by the presence of the Al-based complex, $\mathrm{K}\left[\mathrm{Al}\left(\mathrm{BH}_{4}\right)_{4}\right]$.

We focused our attention on the new bimetallic compound, which we first observed by diffraction in this ternary system. Our further attempts were to obtain and characterize this complex from the binary $\mathrm{KBH}_{4}+\mathrm{Al}\left(\mathrm{BH}_{4}\right)_{3}$ mixture. Two cycles of soaking in excess of $\mathrm{Al}\left(\mathrm{BH}_{4}\right)_{3}$ and its removal in vacuum resulted in samples containing $\sim 70 \mathrm{wt} \%$ of $\mathrm{K}\left[\mathrm{Al}\left(\mathrm{BH}_{4}\right)_{4}\right]$ with $30 \%$ of the remaining $\mathrm{KBH}_{4}$. The yield can be increased to $90 \%$ by a third soaking-vacuum pumping cycle. The important intermediate step in the synthesis is grinding the sample before adding a new portion of $\mathrm{Al}\left(\mathrm{BH}_{4}\right)_{3}$. The sample containing $90.1(5)$ wt $\%$ of $\mathrm{K}\left[\mathrm{Al}\left(\mathrm{BH}_{4}\right)_{4}\right]$ was refined by Rietveld method (see Figure 1a).

In situ synchrotron $\mathrm{XRD}$ in the $30-210{ }^{\circ} \mathrm{C}$ temperature range reveals the decomposition of $\mathrm{K}\left[\mathrm{Al}\left(\mathrm{BH}_{4}\right)_{4}\right]$ at $\sim 180{ }^{\circ} \mathrm{C}$, with an onset at $150-160{ }^{\circ} \mathrm{C}$, into amorphous products and $\mathrm{KBH}_{4}$. Remarkably, the diffraction intensities of the crystalline $\mathrm{KBH}_{4}$ are increasing during the decomposition of $\mathrm{K}\left[\mathrm{Al}\left(\mathrm{BH}_{4}\right)_{4}\right]$ (Figure 1b), showing the maximum at $160{ }^{\circ} \mathrm{C}$ (Figure S5). This observation complements nicely the thermal analysis and mass

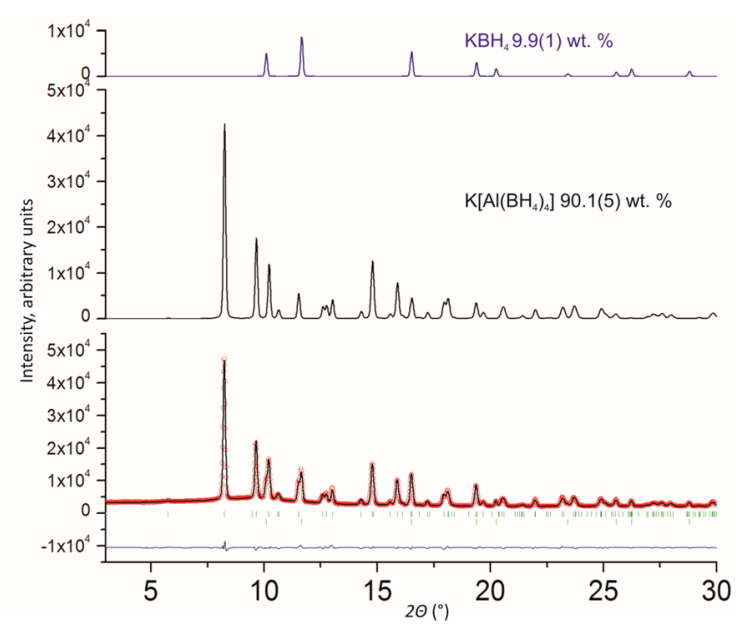

$a$

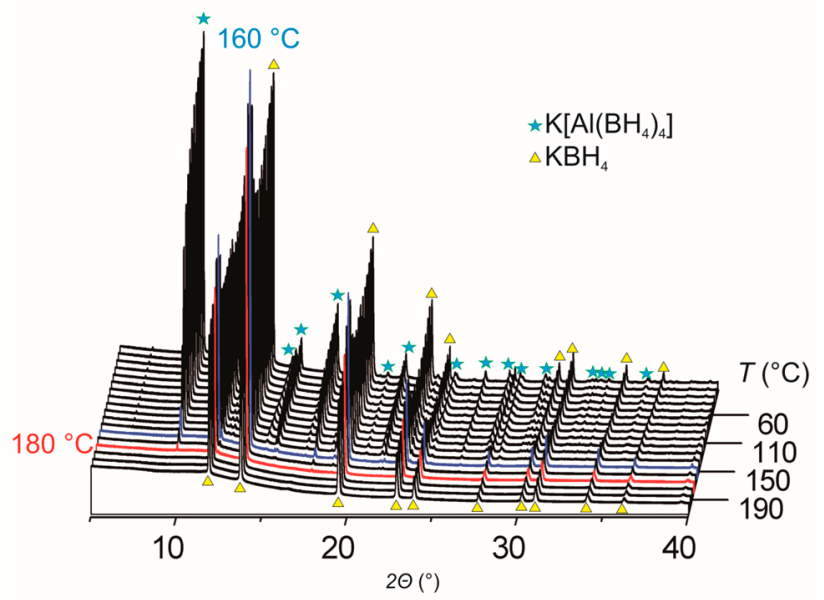

$b$

Figure 1. (a) Low-angle part of the Rietveld refinement profile (extending up to $62^{\circ}$ in $2 \theta$ ) for the ESRF synchrotron data, $\lambda=0.682$ $525 \AA, R_{\mathrm{wp}}=7.55 \% . \mathrm{K}\left[\mathrm{Al}\left(\mathrm{BH}_{4}\right)_{4}\right]$ : space group $\mathrm{Fddd}, a=9.7405(3), b$ $=12.4500(4)$, and $c=14.6975(4) \AA, R_{\mathrm{F}}=3.8 \% ; \mathrm{KBH}_{4}: F m-3 m, a=$ 6.72556(1) $\AA, R_{\mathrm{F}}=3.2 \%$. (b) Temperature evolution of powder diffraction patterns for $\mathrm{K}\left[\mathrm{Al}\left(\mathrm{BH}_{4}\right)_{4}\right] / \mathrm{KBH}_{4}$ mixture from 30 to 210 ${ }^{\circ} \mathrm{C}, \lambda=0.81560 \AA$, SLS. Red line highlights the pattern collected right after the decomposition of $\mathrm{K}\left[\mathrm{Al}\left(\mathrm{BH}_{4}\right)_{4}\right]$ at $180{ }^{\circ} \mathrm{C}$, showing Bragg peaks of $\mathrm{KBH}_{4}$ alone. The blue line shows the maximum intensity of $\mathrm{KBH}_{4}$ at $160{ }^{\circ} \mathrm{C}$.

spectrometric data, helping to suggest a decomposition reaction pathway (see below).

Crystal Structure of $\mathrm{K}\left[\mathrm{AI}\left(\mathrm{BH}_{4}\right)_{4}\right]$. The title compound is the first halide-free bimetallic borohydride containing [Al$\left.\left(\mathrm{BH}_{4}\right)_{4}\right]^{-}$. The other bimetallic Al-based complexes, such as " $\mathrm{Li}_{4} \mathrm{Al}_{3}\left(\mathrm{BH}_{4}\right)_{13}$ ", and $\mathrm{Na}\left[\mathrm{Al}\left(\mathrm{BH}_{4}\right)_{4-x} \mathrm{Cl}_{x}\right],{ }^{9}$ are stabilized by $\mathrm{Cl}-$ substitution on the borohydride sites, as determined by structural refinements. The only $\mathrm{Cl}$-free complex aluminum borohydride, $\left[\mathrm{Ph}_{3} \mathrm{MeP}\right]\left[\mathrm{Al}\left(\mathrm{BH}_{4}\right)_{4}\right]$, contains a bulky organic cation, ${ }^{34}$ making it inappropriate for hydrogen storage applications. Interestingly, a synthesis involving $\mathrm{AlCl}_{3}$ results in the $\mathrm{K}\left[\mathrm{Al}\left(\mathrm{BH}_{4}\right)_{4}\right]$ phase with cell parameters very similar to those of the chlorine-free compound, indicating low or no substitution of $\mathrm{Cl}$ on the $\mathrm{BH}_{4}$ sites (see Supporting Information). 


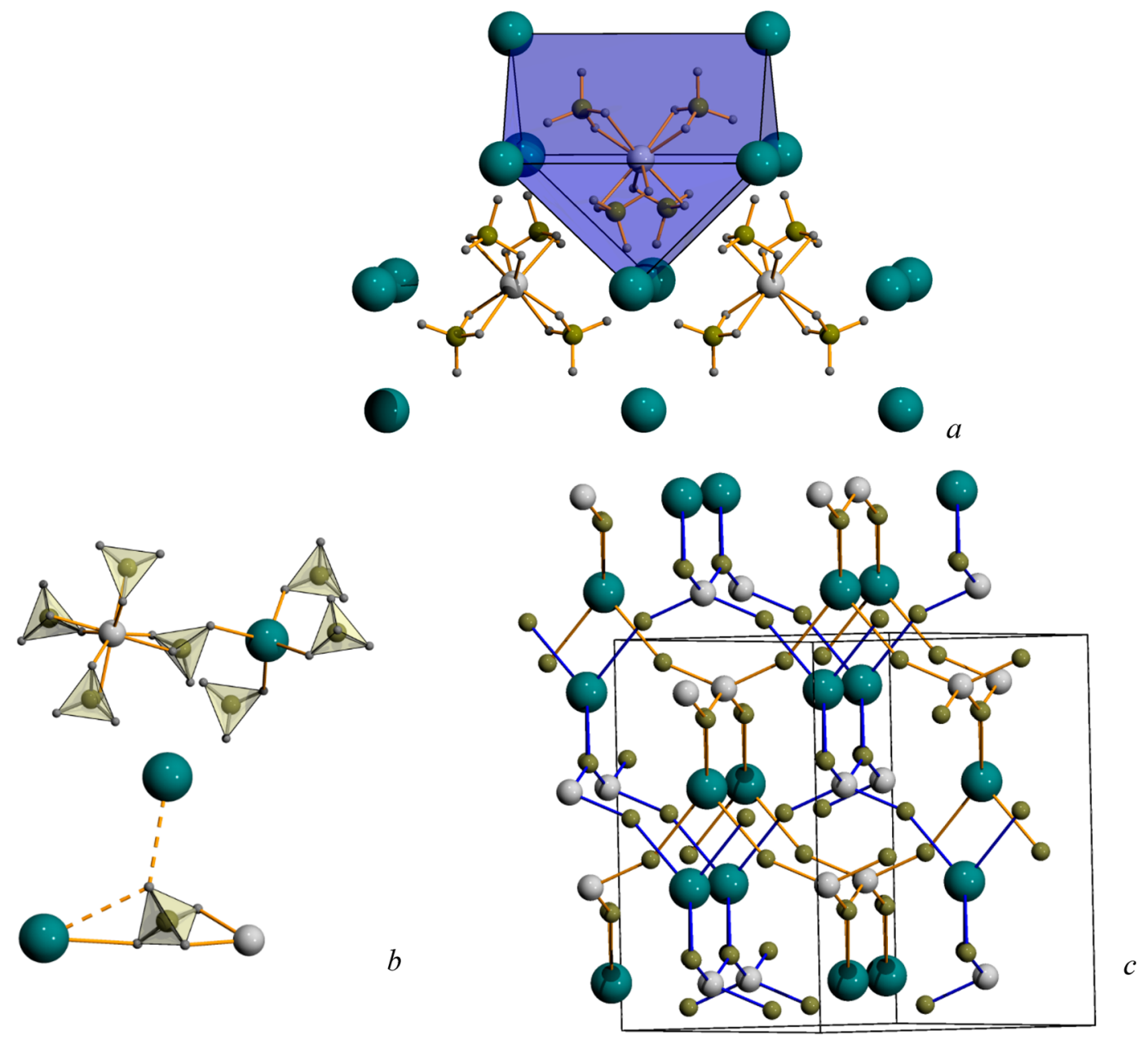

Figure 2. Representations of the crystal structure of $\mathrm{K}\left[\mathrm{Al}\left(\mathrm{BH}_{4}\right)_{4}\right]$. (a) Complex anion $\left[\mathrm{Al}\left(\mathrm{BH}_{4}\right)_{4}\right]^{-}$located in the bicapped trigonal prismatic cage $\mathrm{K}_{8}$. (b) Coordination environment of $\mathrm{K}, \mathrm{Al}$ atoms, and the $\mathrm{BH}_{4}$ group; the dashed lines depict elongated $\mathrm{K} \cdots \mathrm{H}$ distances completing the coordination for $\mathrm{K}$ to $4 \mathrm{H}+8 \mathrm{H}$. (c) Two interpenetrated dia-type nets; hydrogen atoms are omitted for clarity.

$\mathrm{K}\left[\mathrm{Al}\left(\mathrm{BH}_{4}\right)_{4}\right]$ crystallizes in the orthorhombic space group $\mathrm{Fddd}$, as the $\mathrm{LT}-\mathrm{TbAsO}_{4}$ prototype, ${ }^{35}$ with $\mathrm{BH}_{4}{ }^{-}$anions in place of oxygen atoms. The $\mathrm{LT}$ phase of $\mathrm{TbAsO}_{4}$ (stable below $27.7 \mathrm{~K}$ ) is an orthorhombic deformation of the tetragonal HT phase ( $\left(\mathrm{I}_{1} /\right.$ amd, $\mathrm{ZrSiO}_{4}$ type) caused by the Jahn-Teller effect. The orthorhombic structure of $\mathrm{K}\left[\mathrm{Al}\left(\mathrm{BH}_{4}\right)_{4}\right]$, stable until its decomposition, is far from a tetragonal prototype. This is certainly due to much stronger deformation of $\left[\mathrm{Al}\left(\mathrm{BH}_{4}\right)_{4}\right]^{-}$ from an ideal tetrahedron (see below) as compared to $\left[\mathrm{AsO}_{4}\right]^{3-}$.

Metal cations have distorted tetrahedral environments formed by the $\mathrm{BH}_{4}{ }^{-}$groups. Aluminum atoms are coordinated to four anions via the $\mathrm{BH}_{2}$ edges: $\mathrm{Al}-\mathrm{H} 1$ 1.79(1) $\AA$ and $\mathrm{Al}-\mathrm{H} 3$ 1.96(1) $\AA$, forming distorted tetrahedral $\left[\mathrm{Al}\left(\mathrm{BH}_{4}\right)_{4}\right]$ complexes with $\mathrm{B}-\mathrm{Al}-\mathrm{B}$ angles ranging from $97.6(1)^{\circ}$ to $135.4(1)^{\circ}$, very close to $100.0(1)^{\circ}-130.8(2)^{\circ}$ in $\mathrm{Li}_{4} \mathrm{Al}_{3}\left(\mathrm{BH}_{4}\right)_{13}{ }^{8} \mathrm{~K}^{+}$coordinates the anion asymmetrically via an edge: $\mathrm{K}-\mathrm{H} 2$ 2.55(1) $\AA$, $\mathrm{K}-\mathrm{H} 4$ 3.20(1) $\AA$. The $\mathrm{BH}_{4}{ }^{-}$group is coordinated through the vertex to another potassium cation (K-H4 2.92(9) A ), forming T-shaped coordination for the anion and $4+4$ coordination polyhedron for $\mathrm{K}$ with respect to the $\mathrm{BH}_{4}^{-}$groups. Disregarding the more distant potassium atom, the borohydride group acts like a nearly linear bridging ligand with $\mathrm{Al} \cdots \mathrm{B} \cdots \mathrm{K}$ angle of $152.7(2)^{\circ}$, similar to $\mathrm{Mg} \cdots \mathrm{B} \cdots \mathrm{Mg}$ angles in $\mathrm{Mg}\left(\mathrm{BH}_{4}\right)_{2}$ framework structures. ${ }^{36,37}$
The $\mathrm{Al}-\mathrm{B}$ distance of $2.262(4) \AA$ is slightly longer than 2.10-2.15 $\AA$ in $\alpha, \beta-\mathrm{Al}\left(\mathrm{BH}_{4}\right)_{3}$ where $\mathrm{Al}$ coordinates three borohydrides $^{38,39}$ and falls in the 2.22-2.35 $\AA$ range for the tetracoordinated $\mathrm{Al}$ in $\mathrm{Al}_{3} \mathrm{Li}_{4}\left(\mathrm{BH}_{4}\right)_{13},\left[\mathrm{Ph}_{3} \mathrm{MeP}\right]\left[\mathrm{Al}\left(\mathrm{BH}_{4}\right)_{4}\right]$, and $\mathrm{Na}\left[\mathrm{Al}\left(\mathrm{BH}_{4}, \mathrm{Cl}\right)_{4}\right] .{ }^{8,9,34}$ Because of the smaller size of $\mathrm{Al}^{3+}$, the $\mathrm{Al}-\mathrm{B}$ distances are slightly shorter than 2.27-2.38 $\AA \mathrm{Sc}-\mathrm{B}$ and $\mathrm{Y}-\mathrm{B}$ bond distances in $\mathrm{K}\left[\mathrm{Sc}\left(\mathrm{BH}_{4}\right)_{4}\right]$ and $\mathrm{K}\left[\mathrm{Y}\left(\mathrm{BH}_{4}\right)_{4}\right]{ }^{15,16}$ Remarkably, $\mathrm{Y}^{3+}$ and $\mathrm{Sc}^{3+}$ coordinate the $\mathrm{BH}_{4}$ groups via the tetrahedral faces, showing higher coordination numbers and longer metal-hydrogen distances. The short $\mathrm{K}-\mathrm{B}$ distance of 3.285(4) $\AA$ in $\mathrm{K}\left[\mathrm{Al}\left(\mathrm{BH}_{4}\right)_{4}\right](\mathrm{CN}=4+4)$ is similar to the $3.26(1) \AA$ distance in $\mathrm{K}\left[\mathrm{Y}\left(\mathrm{BH}_{4}\right)_{4}\right](\mathrm{CN}=6)^{16}$ and slightly shorter than $3.364 \AA$ in the cubic $\mathrm{KBH}_{4}(\mathrm{CN}=6)^{31}$ or shorter than the short distance of $3.51(4) \AA$ for $\mathrm{CN}=8$ in $\mathrm{K}\left[\mathrm{Sc}\left(\mathrm{BH}_{4}\right)_{4}\right] .{ }^{15}$ The longer $\mathrm{K}-\mathrm{B}$ distance of $3.809(4) \AA$ is comparable to the longest $\mathrm{K}-\mathrm{B}$ distance of $3.95(2) \AA^{15}$ for $\mathrm{CN}$ $=8$ in $\mathrm{K}\left[\mathrm{Sc}\left(\mathrm{BH}_{4}\right)_{4}\right]$. On the other hand, $\mathrm{K}^{+}$with $\mathrm{CN}=7$ in $\mathrm{LiK}\left(\mathrm{BH}_{4}\right)_{2}$ shows more regular $\mathrm{K}-\mathrm{B}$ distances, falling within $3.40-3.47 \AA^{32}$

$\mathrm{K}\left[\mathrm{Al}\left(\mathrm{BH}_{4}\right)_{4}\right]$ is not isomorphic to $\mathrm{KAlCl}_{4}$ and $\mathrm{NaAlCl}_{4}$, where much more regular tetrahedral $\mathrm{AlCl}_{4}{ }^{-}$anions are present, as well as different coordination polyhedra for alkali metal atoms are observed. ${ }^{23,40}$ The title structure can be seen as an ionocovalent compound containing complex anion [Al$\left.\left(\mathrm{BH}_{4}\right)_{4}\right]^{-}$located in the bicapped trigonal prismatic cage $\mathrm{K}_{8}$ 
(Figure 2a). In the related compound, $\mathrm{Na}\left[\mathrm{Al}\left(\mathrm{BH}_{4}\right)_{4-x} \mathrm{Cl}_{x}\right],{ }^{9}$ the complex anion is also located in a deformed square prismatic $\mathrm{Na}_{8}$ cage. The ratio of the average $\mathrm{K}-\mathrm{B}$ to $\mathrm{Al}-\mathrm{B}$ distances of 1.57 is quite large (for comparison with other members see Table 3 in ref 41), indicating an important degree of isolation of the complex anion $\left[\mathrm{Al}\left(\mathrm{BH}_{4}\right)_{4}\right]^{-}$in the $\mathrm{K}_{8}$ cage.

Neglecting four longer $\mathrm{K}-\mathrm{B}$ distances, the structure of $\mathrm{K}\left[\mathrm{Al}\left(\mathrm{BH}_{4}\right)_{4}\right]$ can be also viewed as a framework formed by two diamond nets (or $\mathrm{ZnS}$ nets, considering the $\mathrm{K}$ and $\mathrm{Al}$ ordering), shown in Figure 2c. The two interpenetrated dia-nets are touching each other via one of the two elongated $\mathrm{H} \cdots \mathrm{K} 3.20$ (1) $\AA$ ( $\mathrm{B} \cdots \mathrm{K} 3.809(4) \AA$ ), shown by the dashed line in Figure $2 \mathrm{~b}$. The same topology was found for another complex hydride, $\mathrm{LiZn}_{2}\left(\mathrm{BH}_{4}\right)_{5} \cdot{ }^{10}$ Double interpenetrated frameworks are much more clearly observed in the absence of complex anions, i.e., in the high-pressure $\delta$ - $\mathrm{Mg}\left(\mathrm{BH}_{4}\right)_{2}{ }^{37}$ and two closely related $\mathrm{Cd}\left(\mathrm{BH}_{4}\right)_{2}$ polymorphs. ${ }^{11}$ The topologies typical for coordination frameworks highlight the role of the borohydride anion acting as the bridging directional ligand. ${ }^{42}$

Infrared and Raman Spectroscopy. The strongest bands in the $2100-2600 \mathrm{~cm}^{-1}$ range (Figure 3 ) correspond to $\mathrm{B}-\mathrm{H}$

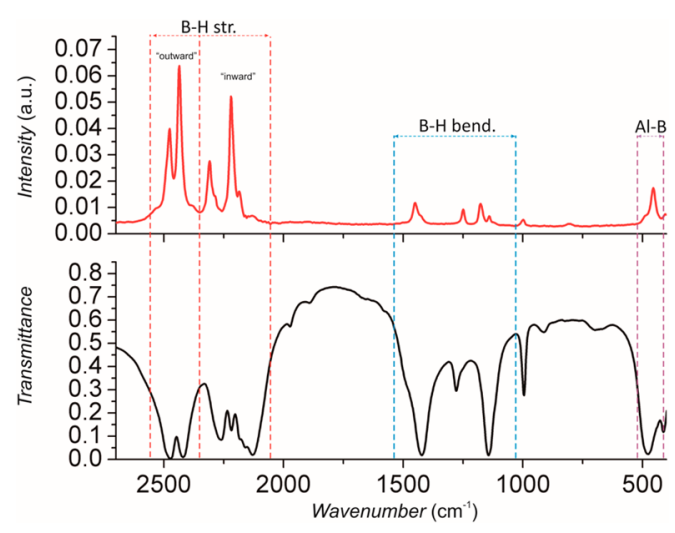

Figure 3. Raman and infrared spectra of $\mathrm{K}\left[\mathrm{Al}\left(\mathrm{BH}_{4}\right)_{4}\right] / \mathrm{KBH}_{4}$ mixture (90.1/9.9 wt \%) at room temperature.

stretching, and less intense peaks from 990 to $1300 \mathrm{~cm}^{-1}$ can be attributed to $\mathrm{B}-\mathrm{H}$ bending modes. Only the strongest peak of $\mathrm{KBH}_{4}$ at $2308 \mathrm{~cm}^{-143}$ can be recognized in stretching mode region in the Raman spectrum, the remaining peaks overlap with $\mathrm{B}-\mathrm{H}$ stretching modes from $\mathrm{K}\left[\mathrm{Al}\left(\mathrm{BH}_{4}\right)_{4}\right]$ : the difference of intensities in spectra for different $\mathrm{K}\left[\mathrm{Al}\left(\mathrm{BH}_{4}\right)_{4}\right] / \mathrm{KBH}_{4}$ ratios is shown in the Supporting Information (Figure S4). The other two peaks at 2436 and $2476 \mathrm{~cm}^{-1}$ from Raman and 2419 and $2472 \mathrm{~cm}^{-1}$ from IR are related to the outward $\mathrm{B}-\mathrm{H}$ stretching modes from $\left[\mathrm{Al}\left(\mathrm{BH}_{4}\right)_{4}\right]^{-}$with respect to the observed in crystal structure bidentate coordination. The mentioned doublet in the $2400-2600 \mathrm{~cm}^{-1}$ range with $50-80 \mathrm{~cm}^{-1}$ splitting is typical for bidentately bridged borohydrides. ${ }^{44,45}$ Similar peaks were seen at 2440 and $2480 \mathrm{~cm}^{-1}$ for $\mathrm{Al}_{3} \mathrm{Li}_{4}\left(\mathrm{BH}_{4}\right)_{13}$ in Raman and at 2420 with $2480 \mathrm{~cm}^{-1}$ in the infrared spectrum as well as 2444 and $2503 \mathrm{~cm}^{-1}$ for $\mathrm{Na}\left[\mathrm{Al}\left(\mathrm{BH}_{4}, \mathrm{Cl}\right)_{4}\right]$ in Raman spectra. ${ }^{8,9}$

In the region of $\mathrm{B}-\mathrm{H}$ bending modes, a band at $1249 \mathrm{~cm}^{-1}$ corresponds to $\mathrm{KBH}_{4}{ }^{34,43}$ The other peaks at 999, 1140, 1177, and $1450 \mathrm{~cm}^{-1}$ in Raman spectrum and 996, 1144, 1278, 1422 $\mathrm{cm}^{-1}$ in the IR can be assigned to the $\mathrm{BH}_{2}$ bending modes in $\left[\mathrm{Al}\left(\mathrm{BH}_{4}\right)_{4}\right]^{-}$, similar to $\mathrm{Al}_{3} \mathrm{Li}_{4}\left(\mathrm{BH}_{4}\right)_{13}$ complex (near 1000, 1020, 1170, and $1450 \mathrm{~cm}^{-1}$ in the Raman spectrum $\left.{ }^{8}\right)$. The sharp bands at 455 and $477 \mathrm{~cm}^{-1}$ in both spectra likely correspond to the $\mathrm{Al}-\mathrm{B}$ stretching mode, also previously seen at $490 \mathrm{~cm}^{-1}$ for $\mathrm{Li}-\mathrm{Al}$ and $\mathrm{Na}-\mathrm{Al}$ complex borohydrides, as well as for the pure $\mathrm{Al}\left(\mathrm{BH}_{4}\right)_{3}{ }^{8,9,46}$

Thermal and Mass Spectrometry Analysis. The TGA and DSC curves of the $\mathrm{K}\left[\mathrm{Al}\left(\mathrm{BH}_{4}\right)_{4}\right] / \mathrm{KBH}_{4}(73.1 / 26.9$ wt \% from XRD) mixture are shown in Figure 4. Only one sharp

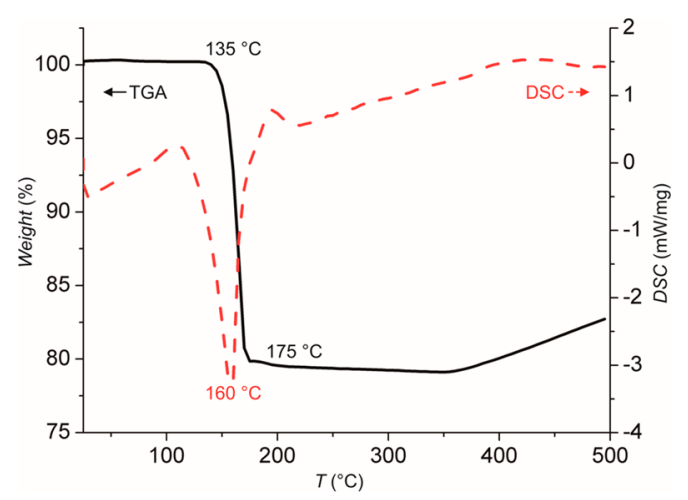

Figure 4. Thermal analysis of $\mathrm{K}\left[\mathrm{Al}\left(\mathrm{BH}_{4}\right)_{4}\right] / \mathrm{KBH}_{4}$ mixture.

endothermic peak with the maximum at $160{ }^{\circ} \mathrm{C}$ was detected by DSC analysis in the $25-500{ }^{\circ} \mathrm{C}$ temperature range. According to the thermogravimetric analysis and in situ XRD, a decomposition of $\mathrm{K}\left[\mathrm{Al}\left(\mathrm{BH}_{4}\right)_{4}\right]$ complex starts at $135{ }^{\circ} \mathrm{C}$ and finishes at $175{ }^{\circ} \mathrm{C}$ (near $180{ }^{\circ} \mathrm{C}$ from XRD). This decomposition profile is significantly different from the previously reported decomposition of presumably pure K[Al$\left.\left(\mathrm{BH}_{4}\right)_{4}\right]$ by Semenenko et al., ${ }^{21}$ where two endothermic peaks were detected at 132 and $240{ }^{\circ} \mathrm{C}$. According to ref 21 , the evolution of diborane and hydrogen was also accompanied by considerable amounts of $\mathrm{Al}\left(\mathrm{BH}_{4}\right)_{3}$ desorbing at $130{ }^{\circ} \mathrm{C}$. The total mass loses of $20.8 \mathrm{wt} \%$ on our sample is equivalent to 28.5 wt \% with respect to the pure $\mathrm{K}\left[\mathrm{Al}\left(\mathrm{BH}_{4}\right)_{4}\right]$. Desorption of $\mathrm{Al}\left(\mathrm{BH}_{4}\right)_{3}$ would lead to a much larger weight loss of 56.9 wt \% for the pure $\mathrm{K}\left[\mathrm{Al}\left(\mathrm{BH}_{4}\right)_{4}\right]$ or 41.8 wt $\%$ for our $\mathrm{K}\left[\mathrm{Al}\left(\mathrm{BH}_{4}\right)_{4}\right]$ / $\mathrm{KBH}_{4}(73.1 / 26.9$ wt \%) sample. According to our diffraction data, the intensity of $\mathrm{KBH}_{4}$ peaks increases upon the decomposition of $\mathrm{K}\left[\mathrm{Al}\left(\mathrm{BH}_{4}\right)_{4}\right]$ (Figure $\mathrm{S} 5$ ), providing $\sim 0.6$ mol of $\mathrm{KBH}_{4}$ upon decomposition of $1 \mathrm{~mol}$ of $\mathrm{K}\left[\mathrm{Al}\left(\mathrm{BH}_{4}\right)_{4}\right]$. Taking together with the TGA data, all the observations can be described by the following hypothetic decomposition reaction 3:

$$
\begin{aligned}
& 2 \mathrm{~K}\left[\mathrm{Al}\left(\mathrm{BH}_{4}\right)_{4}\right] \rightarrow \mathrm{KBH}_{4}+\text { amorphous “ } \mathrm{KAl}_{2} \mathrm{~B}_{3} \text { ” }+2 \mathrm{~B}_{2} \mathrm{H}_{6} \\
& \quad+8 \mathrm{H}_{2}
\end{aligned}
$$

This reaction gives $28.5 \mathrm{wt} \%$ loss of mass, as observed by the TGA. The absence of diffraction peaks in the decomposed products rules out the formation of the anticipated crystalline phases, such as $\mathrm{AlB}_{2}, \mathrm{~K}-\mathrm{B}$ borides, and $\mathrm{KH}$.

We additionally performed two independent mass spectrometry measurements on the evolving gas products, combined with the simultaneous TGA. Atomic mass units 26 and 27 corresponding to $\mathrm{B}_{2} \mathrm{H}_{6}$ and $42,43,56,57$ and $70-73 \mathrm{amu}$ corresponding to $\mathrm{Al}\left(\mathrm{BH}_{4}\right)_{3}$, as observed in decomposition of $\mathrm{Al}_{3} \mathrm{Li}_{4}\left(\mathrm{BH}_{4}\right)_{13}$, were chosen as characteristic fragments. From our data shown in Figure 5, diborane release is clearly observed at $160{ }^{\circ} \mathrm{C}$, fully consistent with the maximum of the endothermic peak seen in DSC and weight losses in TGA and TGA-MS data in Figure 6. Due to the fact that $28 \mathrm{~m} / \mathrm{z}$ signal in the diborane reference data amounts only to 


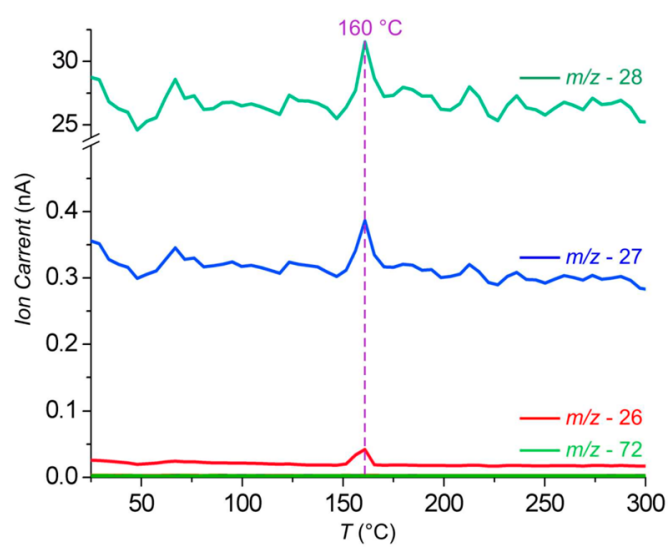

Figure 5. MS curve of evolving gases measured in $25-300{ }^{\circ} \mathrm{C}$ temperature range. The lines close to the zero level show the absence of $\mathrm{Al}\left(\mathrm{BH}_{4}\right)_{3}$ fragments.

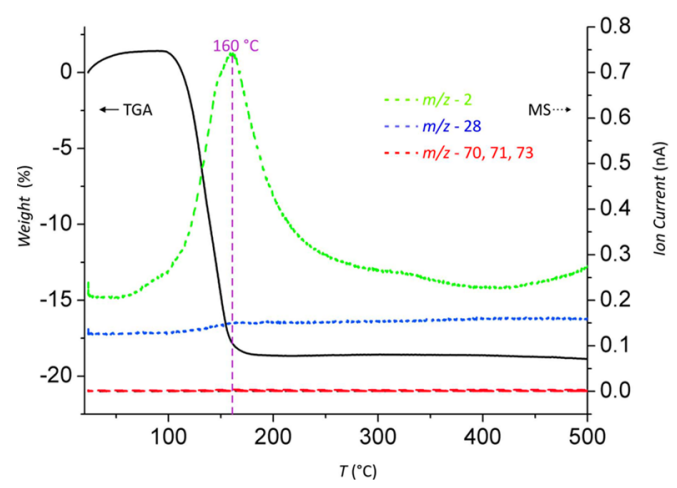

Figure 6. TGA-MS curves in $20-500{ }^{\circ} \mathrm{C}$ temperature range for $\mathrm{K}\left[\mathrm{Al}\left(\mathrm{BH}_{4}\right)_{4}\right] / \mathrm{KBH}_{4}(85 / 15 \mathrm{wt} \%)$ sample. The current for diborane is considerably lower than for hydrogen. The beam current is practically zero for aluminum borohydride.

$\sim 0.5 \%,{ }^{47,48}$ the likely origin of this peak at the decomposition is the release of molecular nitrogen, which was trapped during the synthesis. The evolution of $\mathrm{AlH}^{+}$with $28 \mathrm{~m} / z$ as byproduct is also not feasible because this peak has a much smaller abundance $(\sim 22 \%)$ compared to $27 \mathrm{~m} / z$ for $\mathrm{Al}$, as seen for aluminum hydride (alane) decomposition from hydrogencovered aluminum single crystal surfaces. ${ }^{49}$ At the same time, diborane was observed by IR data from decomposition of $\mathrm{Al}_{3} \mathrm{Li}_{4}\left(\mathrm{BH}_{4}\right)_{13}{ }^{51}$ and $\mathrm{LiZn}_{2}\left(\mathrm{BH}_{4}\right)_{5} ;^{50}$ the former also showed $\mathrm{Al}\left(\mathrm{BH}_{4}\right)_{3}$ desorption and no trace of alane formation. In the case of $\mathrm{K}\left[\mathrm{Al}\left(\mathrm{BH}_{4}\right)_{4}\right]$, we did not observe the fragments of $\mathrm{Al}\left(\mathrm{BH}_{4}\right)_{3}$ in the TGA-MS curve (Figure 6); however, the presence of 42 and 43, 56 and 57 amu likely belonging to $\mathrm{Al}\left(\mathrm{BH}_{4}\right)^{+}$and $\mathrm{Al}\left(\mathrm{BH}_{4}\right)_{2}{ }^{+}$can be recognized in the logarithmic plot of the second TGA-MS experiment (Figure S7). Therefore, the decomposition by the reaction 3 can be affirmed with the maximum intensity of $\mathrm{H}_{2}{ }^{+}$ion current at $160{ }^{\circ} \mathrm{C}$.

This decomposition reaction pathway is different from the one for $\mathrm{Li}-\mathrm{Al}$ borohydride, $\mathrm{Al}_{3} \mathrm{Li}_{4}\left(\mathrm{BH}_{4}\right)_{13}$, desorbing $\mathrm{Al}\left(\mathrm{BH}_{4}\right)_{3}$ under vacuum, ${ }^{51}$ and shows similarities with alkali metalyttrium borohydrides, $\mathrm{M}\left[\mathrm{Y}\left(\mathrm{BH}_{4}\right)_{4}\right]$, decomposing to hydrogen and nonvolatile amorphous $\mathrm{MYB}_{4} \mathrm{H}_{n}(\mathrm{M}=\mathrm{Li}, \mathrm{Na}, \mathrm{Rb}$, Cs and $n$ $=4,3,3,2$, respectively) products. ${ }^{52}$ Our manipulations with $\mathrm{K}\left[\mathrm{Al}\left(\mathrm{BH}_{4}\right)_{4}\right]$ on air show its relatively good stability and nonexplosive character, which is typical even for the smallest amounts of $\mathrm{Al}\left(\mathrm{BH}_{4}\right)_{3}$ vapors. No visible segregation of $\mathrm{Al}\left(\mathrm{BH}_{4}\right)_{3}$ from $\mathrm{K}\left[\mathrm{Al}\left(\mathrm{BH}_{4}\right)_{4}\right]$ upon heating does not exclude that it stays in equilibrium with the starting compounds at temperatures close to ambient, forming a small partial pressure of aluminum borohydride. However, for potential applications in hydrogen storage it is important that this plausible reaction is not observed at elevated temperatures. This prompts further studies on reactive hydride composites capable of suppressing diborane release, and makes $\mathrm{K}\left[\mathrm{Al}\left(\mathrm{BH}_{4}\right)_{4}\right]$ a good candidate for a conversion of aluminum borohydride in a more stable form, to be used for example in reactive hydride composites. ${ }^{53}$

Assessment of Rehydrogenation by in Situ Synchrotron X-ray Powder Diffraction. The sample with $\approx 84 \mathrm{wt} \%$ of $\mathrm{K}\left[\mathrm{Al}\left(\mathrm{BH}_{4}\right)_{4}\right]$ was decomposed by heating up to $210{ }^{\circ} \mathrm{C}$ under 1 bar of $\mathrm{H}_{2}$, using a single crystal sapphire cell shown in Figure $7 \mathrm{a}$. It is the first system with $\left[\mathrm{Al}\left(\mathrm{BH}_{4}\right)_{4}\right]^{-}$anion, characterized for reversibility by this method. Its thermal decomposition behavior reproduces the one under argon (compare Figures $7 \mathrm{~b}$ and $1 \mathrm{~b}$ ). The decomposed material was loaded with 100 bar of $\mathrm{H}_{2}$ at $50{ }^{\circ} \mathrm{C}$, but no changes were observed by diffraction during the first $70 \mathrm{~min}$ (Figure 1c). The sample was heated rapidly to $320^{\circ} \mathrm{C}$ and slowly cooled to the room temperature under 100 bar of hydrogen. We did not observe neither significant changes of intensities from $\mathrm{KBH}_{4}$ of decomposed sample nor a formation of the starting $\mathrm{K}[\mathrm{Al}-$ $\left.\left(\mathrm{BH}_{4}\right)_{4}\right]$ (Figure 1d). Nonreversible character of $\mathrm{K}\left[\mathrm{Al}\left(\mathrm{BH}_{4}\right)_{4}\right]$ decomposition is consistent with evolution of other gaseous species than hydrogen, such as gaseous $\mathrm{B}_{2} \mathrm{H}_{6}$ (see eq 3 ). Therefore, this composition alone is not suitable for direct rehydrogenation; its high hydrogen content allows for development of potentially reversible reactive hydride composites. ${ }^{53}$

Conclusions and Perspective. By direct interaction of potassium and aluminum borohydrides at room temperature, a complex borohydride, $\mathrm{K}\left[\mathrm{Al}\left(\mathrm{BH}_{4}\right)_{4}\right]$, was obtained. According to the synchrotron X-ray powder diffraction study as well as vibrational spectroscopy, it contains distorted tetrahedral $\left[\mathrm{Al}\left(\mathrm{BH}_{4}\right)_{4}\right]^{-}$anions, where the borohydride group is coordinated to aluminum via an edge. This is the first aluminum-based borohydride complex not stabilized by halide anions or by bulky organic cations. $\mathrm{K}\left[\mathrm{Al}\left(\mathrm{BH}_{4}\right)_{4}\right]$ is not isostructural to bimetallic chlorides, where much more regular tetrahedral $\mathrm{AlCl}_{4}^{-}$anions are present. Instead, the complex borohydride is isomorphous to $\mathrm{TbAsO}_{4}$ and reveals an anion $\left[\mathrm{Al}\left(\mathrm{BH}_{4}\right)_{4}\right]^{-}$located in the bicapped trigonal prismatic cage $\mathrm{K}_{8}$. Neglecting four longer $\mathrm{K} \cdots \mathrm{BH}_{4}$ distances, the structure can be also viewed as a framework built of two interpenetrated diatype nets.

In situ X-ray powder diffraction, TGA, DSC, and TGA-MS data consistently show a single step of decomposition at $\sim 160$ ${ }^{\circ} \mathrm{C}$, with an evolution of hydrogen with some amount of diborane. Aluminum borohydride is not released in substantial amounts; however, some crystalline $\mathrm{KBH}_{4}$ forms upon decomposition. This contrasts with the decomposition of chloride-containing $\mathrm{Li}-\mathrm{Al}$ borohydride, producing $\mathrm{Al}\left(\mathrm{BH}_{4}\right)_{3}$. The higher decomposition temperature of $\mathrm{K}\left[\mathrm{Al}\left(\mathrm{BH}_{4}\right)_{4}\right]$ compared to the chloride-substituted $\mathrm{Li}-\mathrm{Al}\left(70{ }^{\circ} \mathrm{C}\right)$ and $\mathrm{Na}-\mathrm{Al}\left(90{ }^{\circ} \mathrm{C}\right)$ borohydrides suggests that the larger alkali metal cations (weaker Pearson acids) stabilize the weak Pearson base, $\left[\mathrm{Al}\left(\mathrm{BH}_{4}\right)_{4}\right]^{-}$. The hypothetic alkali earth aluminum borohydrides, such as $\mathrm{M}\left[\mathrm{Al}\left(\mathrm{BH}_{4}\right)_{4}\right]_{2}$, are therefore expected to be unstable. On the contrary, the heavier alkali metal aluminum borohydrides, such as the title compound, are good candidates for storage of aluminum borohydride in a more stable form. This prompts further studies on reactive hydride composites, 

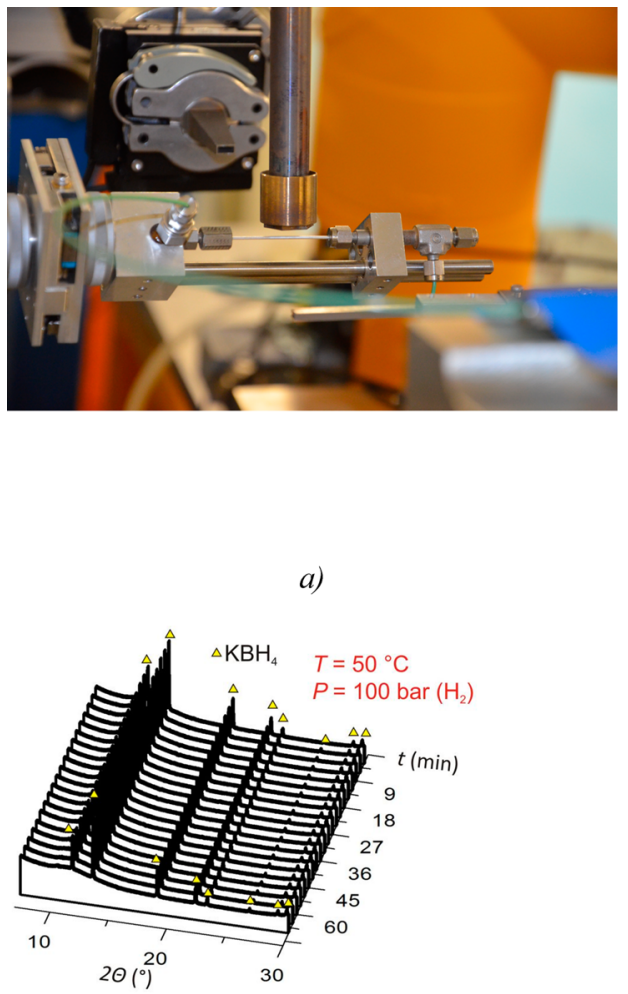

c)

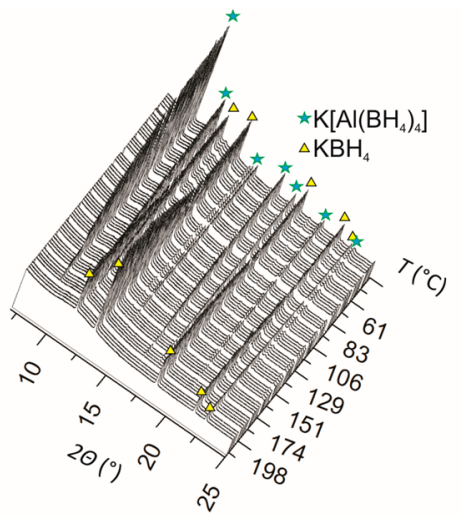

b)

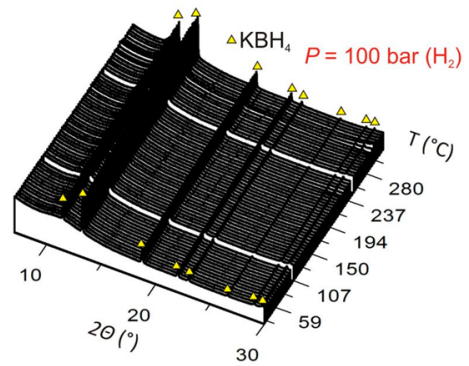

d)

Figure 7. (a) Sapphire capillary filled with the sample and connected to the gas dosing system in the in situ synchrotron X-ray powder diffraction experiment. (b) Temperature evolution of powder diffraction patterns for $\mathrm{K}\left[\mathrm{Al}\left(\mathrm{BH}_{4}\right)_{4}\right] / \mathrm{KBH}_{4}$ mixture from 30 to $210{ }^{\circ} \mathrm{C}$ under 1 bar of $\mathrm{H}_{2}$, resulting in the complete decomposition of $\mathrm{K}\left[\mathrm{Al}\left(\mathrm{BH}_{4}\right)_{4}\right], \lambda=0.775045 \AA$, Material Science beamline at SLS. (c) Rehydrogenation of the decomposed $\mathrm{K}\left[\mathrm{Al}\left(\mathrm{BH}_{4}\right)_{4}\right] / \mathrm{KBH}_{4}$ mixture at $50{ }^{\circ} \mathrm{C}$ and 100 bar of $\mathrm{H}_{2}$ for $70 \mathrm{~min}$. (d) Rehydrogenation of the decomposed $\mathrm{K}\left[\mathrm{Al}\left(\mathrm{BH}_{4}\right)_{4}\right] / \mathrm{KBH}_{4}$ mixture at 100 bar of $\mathrm{H}_{2}$ starting from $320{ }^{\circ} \mathrm{C}$ upon $10{ }^{\circ} \mathrm{C} / \mathrm{min}$ cooling to room temperature.

such as $\mathrm{K}\left[\mathrm{Al}\left(\mathrm{BH}_{4}\right)_{4}\right]$ plus a binary metal hydride, potentially capable to suppress diborane release.

After initial submission of our work, an independent study by Knight et al. was published, ${ }^{54}$ reporting the crystal structure of $\mathrm{K}\left[\mathrm{Al}\left(\mathrm{BH}_{4}\right)_{4}\right]$ in a noncentrosymmetric space group $\mathrm{Fdd} 2$. They did solid-state NMR and volumetric studies, which complement well our MS study of the decomposition and the assessment of rehydrogenation via in situ diffraction. Knight et al. report higher TGA mass loss on the decomposition, attributing it to a release of $\mathrm{Al}\left(\mathrm{BH}_{4}\right)_{3}$.

\section{ASSOCIATED CONTENT}

\section{S Supporting Information}

Supplementary XRD data, Rietveld refinements, Raman spectra, temperature evolution of diffraction intensities, MS data, and a CIF file. This material is available free of charge via the Internet at http://pubs.acs.org.

\section{AUTHOR INFORMATION}

\section{Corresponding Author}

*Fax +32 104727 07, e-mail yaroslav.filinchuk@uclouvain.be (Y.F.).

\section{Notes}

The authors declare no competing financial interest.

\section{ACKNOWLEDGMENTS}

This work was supported by the Académie Universitaire Louvain (AUL), Belgium, under Grant ADi/DB/1058.2011, by the Fonds de la Recherche Scientifique (FNRS), Belgium, under Grant 1.5169.12, and by the Swiss National Science Foundation. We are grateful to the Swiss-Norwegian Beamlines at the ESRF and the Materials Science Beamline at SLS for beamtime allocation and support. The research leading to these results has received funding from the European Community's Seventh Framework Programme (FP7/2007-2013) under grant agreement $n .{ }^{\circ} 312284$ (CALIPSO). We thank J.-F. Statsyns for his help with TGA-MS measurements.

\section{REFERENCES}

(1) Orimo, S.; Nakamori, Y.; Eliseo, J. R.; Züttel, A.; Jensen, C. M. Complex Hydrides for Hydrogen Storage. Chem. Rev. 2007, 107, 4111-4132.

(2) Klebanoff, L. E.; Keller, J. O. 5 Years of Hydrogen Storage Research in the U.S. DOE Metal Hydride Center of Excellence (MHCoE). Int. J. Hydrogen Energy 2013, 38, 4533-4576.

(3) Züttel, A.; Rentsch, S.; Fischerb, P.; Wengera, P.; Sudana, P.; Maurona, Ph.; Emmenegger, Ch. Hydrogen Storage Properties of $\mathrm{LiBH}_{4}$. J. Alloys Compd. 2003, 356-357, 515-520.

(4) Chłopek, K.; Frommen, C.; Lèon, A.; Zabara, O.; Fichtner, M. Synthesis and Properties of Magnesium Tetrahydroborate, $\mathrm{Mg}\left(\mathrm{BH}_{4}\right)_{2}$. J. Mater. Chem. 2007, 17, 3496-3503.

(5) Schrauzer, G. N. Uber ein Periodensystem der Metallboranate. Naturwissenschaften 1955, 42, 438.

(6) Nakamori, Y.; Miwa, K.; Ninomiya, A.; Li, H.; Ohba, N.; Towata, S.; Züttel, A.; Orimo, S. Correlation Between Thermodynamical Stabilities of Metal Borohydrides and Cation Electronegativities: First Principles Calculations and Experiments. Phys. Rev. B 2006, 74, 45126. 
(7) Grochala, W.; Edwards, P. P. Thermal Decomposition of the Non-Interstitial Hydrides for the Storage and Production of Hydrogen. Chem. Rev. 2004, 104, 1283-1315.

(8) Lindemann, I.; Ferrer, R. D.; Dunsch, L.; Filinchuk, Y.; Černý, R.; Hagemann, H.; D’Anna, V.; Daku, L. M. L.; Schultz, L.; Gutfleisch, O. $\mathrm{Al}_{3} \mathrm{Li}_{4}\left(\mathrm{BH}_{4}\right)_{13}$ : a Complex Double-Cation Borohydride with a New Structure. Chem.-Eur. J. 2010, 16, 8707-8712.

(9) Lindemann, I.; Ferrer, R. D.; Dunsch, L.; Cerný, R.; Hagemann, H.; D’Anna, V.; Filinchuk, Y.; Schultz, L.; Gutfleisch, O. Novel Sodium Aluminum Borohydride Containing the Complex Anion [Al$\left.\left(\mathrm{BH}_{4}, \mathrm{Cl}\right)_{4}\right]^{-}$. Faraday Discuss. 2011, 151, 231-242.

(10) Ravnsbæk, D. B.; Filinchuk, Y.; Cerenius, Y.; Jakobsen, H. J.; Besenbacher, F.; Skibsted, J.; Jensen, T. R. Angew. Chem., Int. Ed. 2009, 48, 6659-6663.

(11) Ravnsbæk, D.; Sørensen, L. H.; Filinchuk, Y.; Besenbacher, F.; Jensen, T. R. A Series of Mixed-Metal Borohydrides. Angew. Chem., Int. Ed. 2012, 51, 3582-3586.

(12) Friedrichs, O.; Remhof, A.; Borgschulte, A.; Buchter, F.; Oriomo, S. I.; Züttel, A. Breaking the Passivation-the Road to a Solvent Free Borohydride Synthesis. Phys. Chem. Chem. Phys. 2010, 12, 10919-10922.

(13) Kim, K. C.; Hwang, S.-J.; Bowman, R. C., Jr.; Reiter, J. W.; Zan, J. A.; Kulleck, J. G.; Kabbour, H.; Majzoub, E. H.; Ozolins, V. $\mathrm{LiSc}\left(\mathrm{BH}_{4}\right)_{4}$ as a Hydrogen Storage Material: Multinuclear HighResolution NMR and First-Principals Density Functional Theory Studies. J. Phys. Chem. C 2009, 113, 9956-9968.

(14) Černý, R.; Severa, G.; Ravnsbæk, D. B.; Filinchuk, Y.; D’Anna, V.; Hagemann, H.; Haase, D.; Jensen, C. M.; Jensen, T. R. $\mathrm{NaSc}\left(\mathrm{BH}_{4}\right)_{4}:$ A Novel Scandium-Based Borohydride. J. Phys. Chem. C 2010, 114, 1357-1364.

(15) Černý, R.; Severa, G.; Ravnsbæk, D. B.; Filinchuk, Y.; D’Anna, V.; Hagemann, H.; Haase, D.; Skibsted, J.; Jensen, C. M.; Jensen, T. R. Structure and Characterization of $\mathrm{KSc}\left(\mathrm{BH}_{4}\right)_{4}$. J. Phys. Chem. C 2010, 114, 19540-19549.

(16) Jaroń, T.; Grochala, W. Probing Lewis Acidity of $\mathrm{Y}\left(\mathrm{BH}_{4}\right)_{3}$ via Its Reactions with $\mathrm{MBH}_{4}\left(\mathrm{M}=\mathrm{Li}, \mathrm{Na}, \mathrm{K}, \mathrm{N}(\mathrm{Me})_{4}\right)$. Dalton Trans. 2011, $40,12808-12817$.

(17) Huot, J.; Ravnsbæk, D. B.; Zhang, J.; Cuevas, F.; Latroche, M.; Jensen, T. R. Mechanochemical Synthesis of Hydrogen Storage Materials. Prog. Mater. Sci. 2013, 58, 30-75.

(18) Hagemann, H.; Černý, R. Synthetic Approaches to Inorganic Borohydrides. Dalton Trans. 2010, 39, 6006-6012.

(19) Ravnsbæk, D. B.; Sørensen, L. H.; Filinchuk, Y.; Reed, D.; Book, D.; Jacobsen, H. J.; Besenbacher, F.; Skibsted, J.; Jensen, T. R. MixedAnion and Mixed-Cation Borohydride $\mathrm{KZn}\left(\mathrm{BH}_{4}\right) \mathrm{Cl}_{2}$ : Synthesis, Structure and Thermal Decomposition. Eur. J. Inorg. Chem. 2010, $1608-1612$.

(20) Schlesinger, H. I.; Sanderson, R. T.; Burg, A. B. Metallo Borohydrides. I. Aluminum Borohydride. J. Am. Chem. Soc. 1940, 62, $3421-3425$.

(21) Semenenko, K. N.; Kravchenko, O. V. Complex Compounds of Aluminium Tetrahydroborate with Potassium Chloride and Potassium Tetrahydroborate. Russ. J. Inorg. Chem. 1972, 17, 1084-1086.

(22) Schlesinger, H. I.; Brown, H. C.; Hyde, E. K. Preparation of Other Borohydrides by Metathetical Reactions Utilizing the Alkali Metal Borohydrides. J. Am. Chem. Soc. 1953, 75, 209-213.

(23) Mairesse, G.; Barbier, P.; Wignacourt, J.-P. Potassium Tetrachloroaluminate. Acta Crystallogr. 1978, B34, 1328-1330.

(24) Hammersley, A. P.; Svensson, S. O.; Hanfland, M.; Fitch, A. N.; Häusermann, D. Two-Dimensional Detector Software: From Real Detector to Idealized Image or Two-Theta Scan. High Pressure Res. 1996, 14, 235-248.

(25) Willmott, P. R.; Meister, D.; Leake, S. J.; Lange, M.; Bergamaschi, A.; Böge, M.; Calvi, M.; Cancellieri, C.; Casati, N.; Cervellino, A.; et al. The Materials Science beamline upgrade at the Swiss Light Source. Synchrotron Radiat. 2013, 20, 667-682.

(26) Jensen, T. R.; Nielsen, T. K.; Filinchuk, Y.; Jørgensen, J.-E.; Cerenius, Y.; Gray, E. M.; Webb, C. J. Versatile In Situ Powder X-Ray
Diffraction Cells for Solid-Gas Investigations. J. Appl. Crystallogr. 2010, 43, 1456-1463

(27) Favre-Nicolin, V.; Černý, R. FOX, 'Free Objects for Crystallography': a Modular Approach to Ab Initio Structure Determination from Powder Diffraction. J. Appl. Crystallogr. 2002, $35,734-743$

(28) Rodriguez-Carvajal, J. Recent Advances in Magnetic Structure Determination by Neutron Powder Diffraction. J. Physica B 1993, 192, 55-69.

(29) Spek, A. L. PLATON, University of Utrecht, The Netherlands, 2006.

(30) Soulié, J.-P.; Renaudin, G.; Černý, R.; Yvon, K. Lithium BoroHydride $\mathrm{LiBH}_{4}$ I. Crystal Structure. J. Alloys Compd. 2002, 346, 200205 .

(31) Filinchuk, Y.; Chernyshov, D.; Dmitriev, V. Light Metal Borohydrides: Crystal Structures and Beyond. Z. Kristallogr. 2008, 223, 649-659.

(32) Nickels, E. A.; Jones, M. O.; David, W. I .F.; Johnson, S. R.; Lowton, R. L.; Sommariva, M.; Edwards, P. P. Tuning the Decomposition Temperature in Complex Hydrides: Synthesis of Mixed Alkali-Metal Borohydride. Angew. Chem., Int. Ed. 2008, 47, 2817-2819.

(33) Kim, K. C.; Sholl, D. S. Crystal Structures and Thermodynamic Investigations of $\mathrm{LiK}\left(\mathrm{BH}_{4}\right)_{2}, \mathrm{KBH}_{4}$ and $\mathrm{NaBH}_{4}$ from First Principles Calculations. J. Phys. Chem. C 2010, 114, 678-686.

(34) Dou, D.; Liu, J.; Krause Bauer, J. A.; Jordan, G. T., IV; Shore, S. G. Synthesis and Structure of Triphenylmethylphosphonium Tetrakis(tetrahydroborato)aluminate, $\left[\mathrm{Ph}_{3} \mathrm{MeP}\right]\left[\mathrm{Al}\left(\mathrm{BH}_{4}\right)_{4}\right]$ an Example of Eight-Coordinate Aluminum(III). Inorg. Chem. 1994, 33, 5443-5447.

(35) Schäfer, W.; Will, G.; Müller-Vogt, G. Refinement of the Crystal Structure of Terbium Arsenate $\mathrm{TbAsO}_{4}$ at 77 and $5 \mathrm{~K}$ by Profile Analysis from Neutron Diffraction Powder Data. Acta Crystallogr. 1979, B35, 588-592.

(36) Filinchuk, Y.; Černý, R.; Hagemann, H. Insight into $\mathrm{Mg}\left(\mathrm{BH}_{4}\right)_{2}$ with Synchrotron X-ray Diffraction: Structure Revision, Crystal Chemistry and Anomalous Thermal Expansion. Chem. Mater. 2009, 21, 925-933.

(37) Filinchuk, Y.; Richter, B.; Jensen, T. R.; Dmitriev, V.; Chernyshov, D.; Hagemann, H. Porous and Dense Magnesium Borohydride Frameworks: Synthesis, Stability, and Reversible Absorption of Guest Species. Angew. Chem., Int. Ed. 2011, 50, $11162-11166$.

(38) Aldridge, S.; Blake, A. J.; Downs, A. J.; Gould, R. O.; Parsons, S.; Pulham, C. R. Some Tetrahydroborate Derivatives of Aluminum: Crystal Structures of Dimethylaluminium Tetrahydroborate and the $\alpha$ and $\beta$ Phases of Aluminum Tris(tetrahydroborate) at Low Temperature. J. Chem. Soc., Dalton Trans. 1997, 1007-1012.

(39) Almenningen, A.; Gundersen, G.; Haaland, A. On the Molecular Structure of Aluminum Borohydride, $\mathrm{Al}\left(\mathrm{BH}_{4}\right)_{3}$. Acta Chem. Scand. $1968,22,328-334$.

(40) Krebs, B.; Greiwing, H.; Brendel, C. J.; Taulelle, F.; GauneEscard, M.; Berg, R. W. Crystallographic and Aluminum-27 NMR Study on Premelting Phenomena in Crystals of Sodium Tetrachloroaluminate. Inorg. Chem. 1991, 30, 981-988.

(41) Schouwink, P.; D’Anna, V.; Brix Ley, M.; Lawson Daku, L. M.; Richter, B.; Jensen, T. R.; Hagemann, H. Černý, R. Bimetallic Borohydrides in the System $\mathrm{M}\left(\mathrm{BH}_{4}\right)-\mathrm{KBH}_{4}(\mathrm{M}=\mathrm{Mg}, \mathrm{Mn})$ : On the Structural Diversity. J. Phys. Chem. C 2012, 116, 10829-10840.

(42) Rude, L. H.; Nielsen, T. K.; Ravnsbæk, D. B.; Bösenberg, U.; Ley, M. B.; Richter, B.; Arnbjerg, L. M.; Dornheim, M.; Filinchuk, Y.; Besenbacher, F.; et al. Tailoring Properties of Borohydrides for Hydrogen Storage: A Review. Phys. Status Solidi A 2011, 208, 17541773.

(43) Renaudin, G.; Gomes, S.; Hagemann, H.; Keller, L.; Yvon, K. Structural and Spectroscopic Studies on the Alkali Borohydrides $\mathrm{MBH}_{4}(\mathrm{M}=\mathrm{Na}, \mathrm{K}, \mathrm{Rb}, \mathrm{Cs})$. J. Alloys Compd. 2004, 375, 98-106.

(44) Marks, T. J.; Kolb, J. R. Covalent Transition Metal, Lanthanide, and Actinide Tetrahydroborate Complexes. Chem. Rev. 1977, 77, 263293. 
(45) Makhaev, V. D. Structural and Dynamical Properties of Tetrahydroborate Complexes Russ. Chem. Rev. 2000, 69, 727-746.

(46) Coe, D. A.; Nibler, J. W. Infrared and Raman Spectra of Aluminum Borohydride, $\mathrm{Al}\left(\mathrm{BH}_{4}\right)_{3}$. Spectrochim. Acta 1973, 29A, 1789-1804.

(47) Dibeler, V. H.; Mohler, F. L. The Dissociation of Diborane by Electron Impact. J. Am. Chem. Soc. 1948, 70, 987-989.

(48) NIST Chemistry WebBook, Mass Spectrum and Infrared Spectrum of Diborane, NIST Number 20; National Institute of Standards and Technology: Gaithersburg, MD, 2005.

(49) Winkler, A.; Resch, Ch.; Redulic, K. D. Aluminum Hydride Desorption from Hydrogen Covered Aluminum Single Crystal Surfaces. J. Chem. Phys. 1991, 95, 7682-7688.

(50) Borgshulte, A.; Callini, E.; Probst, B.; Jain, A.; Kato, S.; Friedrichs, O.; Remhof, A.; Bielmann, M.; Ramirez-Cuesta, A. J.; Züttel, A. Impurity Gas Analysis of the Decomposition of Complex Hydrides. J. Phys. Chem. C 2011, 115, 17220-17226.

(51) Lindemann, I.; Borgschulte, A.; Callini, E.; Züttel, A.; Schultz, L.; Gutfleisch, O. Insight into the Decomposition Pathway of the Complex Hydride $\mathrm{Al}_{3} \mathrm{Li}_{4}\left(\mathrm{BH}_{4}\right)_{13}$. Int. J. Hydrogen Energy 2013, 38, 2790-2795.

(52) Jaroń, T.; Wegner, W.; Grochala, W. $\mathrm{M}\left[\mathrm{Y}\left(\mathrm{BH}_{4}\right)_{4}\right]$ and $\mathrm{M}_{2} \mathrm{Li}\left[\mathrm{Y}\left(\mathrm{BH}_{4}\right)_{6-\mathrm{x}} \mathrm{Cl}_{\mathrm{x}}\right](\mathrm{M}=\mathrm{Rb}, \mathrm{Cs})$ : New Borohydride Derivatives of Yttrium and Their Hydrogen Storage Properties. Dalton Trans. 2013, 42, 6886-6893.

(53) Alapati, S. V.; Johnson, J. K.; Sholl, D. S. Large-scale Screening of Metal Hydride Mixtures for High-Capacity Hydrogen Storage from First-Principles Calculations. J. Phys. Chem. C 2008, 112, 5258-5262.

(54) Knight, D. A.; Zidan, R.; Lascola, R.; Mohtadi, R.; Ling, C.; Sivasubramanian, P.; Kaduk, J. A.; Hwang, S.-J.; Samanta, D.; Jena, P. Synthesis, Characterization, and Atomistic Modeling of Stabilized Highly Pyrophoric $\mathrm{Al}\left(\mathrm{BH}_{4}\right)_{3}$ via the Formation of the Hypersalt $\mathrm{K}\left[\mathrm{Al}\left(\mathrm{BH}_{4}\right)_{4}\right]$. J. Phys. Chem. C 2013, 117, 19905-19915. 